\title{
ENSURING THE STERILITY OF SUBSTITUTION THERAPY MEDICATIONS FOR DRY-EYE SYNDROME TREATMENT AFTER OPENING THE ORIGINAL PACKAGING
}

\author{
Yuliia Tomashevska \\ Ph.D. in Pharmaceutical Sciences, Associate Professor, Associate Professor \\ at the Department of Pharmacy, National Pirogov Memorial Medical University, Ukraine \\ e-mail: tomasevskau@gmail.com,orcid.org/0000-0001-9708-1887
}

\section{Olena Kryvoviaz}

Sc.D. in Pharmaceutical Sciences, Professor, Head of the Department of Pharmacy, National Pirogov Memorial Medical University, Ukraine e-mail: olena.kryvoviaz@vnmu.edu.ua,orcid.org/0000-0001-5441-1903

\section{Summary}

The aim of the article is to study the assortment of the additive agents in the composition of dry-eye syndrome substitution therapy medications registered in Ukraine, which may increase the anti-microbial stability of the solution as well as types of packaging of preservative free substitution therapy medications.

The methodology of the research includes the content-analysis of the information on the substitution therapy medications composition, provided in the insert of the medication as well as the study of the type of original packaging and the way it influences the preservation of sterility and properties of the substitution therapy medications.

Provision of clear information in the labeling and the insert of the medication regarding the presence, name and quantity of a preservative (with the use of the term "preservative") is a necessary and often one of the determining factors in treatment selection for patients with dry-eye syndrome. This is determined by the fact that certain agents (or their combination) may perform different functions in a medical form acting, depending on the, for instance, concentration, as preservatives, components of buffer solutions, antioxidants or isotonic substances.

The results of the study show that as of December, 2020 only a few of substitution therapy medications presented on the pharmaceutical market of Ukraine contain such information.

Keywords: eye medications, anti-microbial stability, preservatives, containers.

DOI: https://doi.org/10.23856/4433

\section{Introduction}

In the recent years the dry eye syndrome (DES) issue is becoming a global one. Dry eye syndrome is a civilization disease, which is characterized by a progressing and chronic nature (Craig et al., 2017). The change of the "format of life" (online-learning, working in a distance format, increased duration of staying indoors, self-isolation etc.) leads to the increase of the share of people with the stated disease in the population, particularly, due to the increased time of the influence of ethiopathogenetic factors. Thus, the specialists should pay more attention to all the stages of treating patients (diagnosing, therapy) that visit an ophthalmologist with eye symptoms or even those who are under the influence of risk factors for DES development (Jones et al., 2017). 
DES is characterized by a chronic and progressing nature and includes the distortion of one or several layers of the tear film (aqueous, mucin, lipid). Thus, such processes as disorders in the production of tears, mucins and lipids; the tear evaporation time; tear film formation on the surface of the corneal epithelium underlie the pathogenesis of the "dry eye" syndrome (Bron et al., 2017).

The use of preservatives in the composition of eye drops is considered to be one of the etiological factors of DES development. Namely, such a connection is confirmed by the results of the study of benzalkonium chloride (BAC) (Epstein et al, 2009; Makarenko et al, 2015). According to the research data, the BAC toxicity largely manifests itself on the surface of the eye, in the conjunctiva and corneal epithelium. At the same time, BAC practically does not penetrate into the aqueous humour during the short-term application. The level of BAC toxicity for the ocular surface is directly proportional to the degree of damage to the ocular surface, the duration and frequency of instillations (Elmer, 2014).

Moreover, it states that the application of benzalkonium chloride on the ocular mucous membrane leads to the shortening of the tear film break-up time, which may considerably distort the results of the study among patients with DES (Jones et al., 2017).

DES therapy is aimed at the treatment of ocular symptoms through the correction of the detected quantitative and qualitative disproportions of the tear film layers (Bron et al., 2017; Jones et al., 2017).

DES is generally classified by a combination of symptoms and signs. Judging by both symptoms and signs, DES may be light, medium or severe, however, symptoms are domineering in the diagnosing process (McMonnies, 2021; Syndrom sukhoho oka. Klinichna nastanova, zasnovana na dokazakh, 2019).

Eye medications designed as substitution therapy for DES are presented on the pharmaceutical market of Ukraine in liquid and soft forms (Derzhavnyj reyestr likars'kykh zasobiv Ukrayiny, 2019; Derzhavnyj reyestr medychnoyi tekhniky ta vyrobiv medychnoho pryznachennya, 2019; Dovidnyk likars'kykh zasobiv Kompendium, 2019). According to the requirements of the State Pharmacopoeia of Ukraine, the production of such medications is carried out with the use of materials and methods that ensure the sterility and prevent microbial contamination. Airtight containers with the control of the first opening must be the original packaging for eye disorders medications (Derzhavna farmakopeia Ukrainy 2-e vyd, 2015).

In case eye medications are packaged in single-dose containers, it is not necessary to include additive agents that would ensure the sterility after the opening of the original packaging (Derzhavna farmakopeia Ukrainy 2-e vyd, 2015); Marx \& Birkhoff, 2010; Marx \& Birkhoff, 2015).

While developing eye medications that are sold in multi-dose containers, antimicrobial preservatives may be added to their composition with an obligatory mention of the name of each of them on the label or some special corking tools for the containers may be used (Derzhavna farmakopeia Ukrainy 2-e vyd, 2015).

\section{Purpose}

The purpose of the article is to study the assortment of the additive agents in the composition of DES STMs registered in Ukraine, which may increase the anti-microbial stability of the solution as well as types of packaging of preservative free STMs (single-dose containers and reusable vials sealed with specific corks and mechanisms to ensure the sterility of eye drops after the original package is opened).

The methodology of the research includes the content-analysis of the information on the STM composition, provided in the insert of the medication (instruction for medical application 
of a medication, instruction on the use of the medication and instruction on the use) as well as the study of the type of original packaging and the way it influences the preservation of sterility and properties of the STMs. In addition, in order to detect whether the producer indicated the presence / absence of a preservative in the composition of a DES STM, the article analyses the information, provided on the labeling of the original packaging as well as on the secondary packaging of the group of medications. To update the information on the assortment of STMs that are present o the national pharmaceutical market, we have compared the data received in 2019 and the indices of the $4^{\text {th }}$ quarter of 2020.

\section{Market Dynamics of DES STMs}

According to the marketing analysis of STMs presented on the pharmaceutical market of Ukraine as of the $3^{\text {rd }}$ quarter of 2019, 11 medications of Group S01X A20 "Artificial substitutes of the tear liquid and other neutral medications" and 24 medical products: 1 multi-purpose solution, 16 products for ophthalmological use and 7 solutions for washing, irrigation, treatment, which are presented in 4 drug forms (eye drops, eye gels, solutions, emulsions) (Kryvoviaz \& Tomashevska, 2019).

As of December, 2020, the market expanded due to the occurrence of 12 STMs, 10 and $15 \mathrm{ml}$ in volume in multi-dose containers, of which 7 are registered "Medical products. Products for ophthalmological use" and 5 as "Medical products. Solutions for washing, irrigation, treatment". Thus the increase in physical terms is $25.5 \%$. While segmenting them by the drug form and producing country it has been determined that 11 of them are eye drops of foreign production and 1 is an ophthalmological solution produced in Ukraine (Fig. 1).

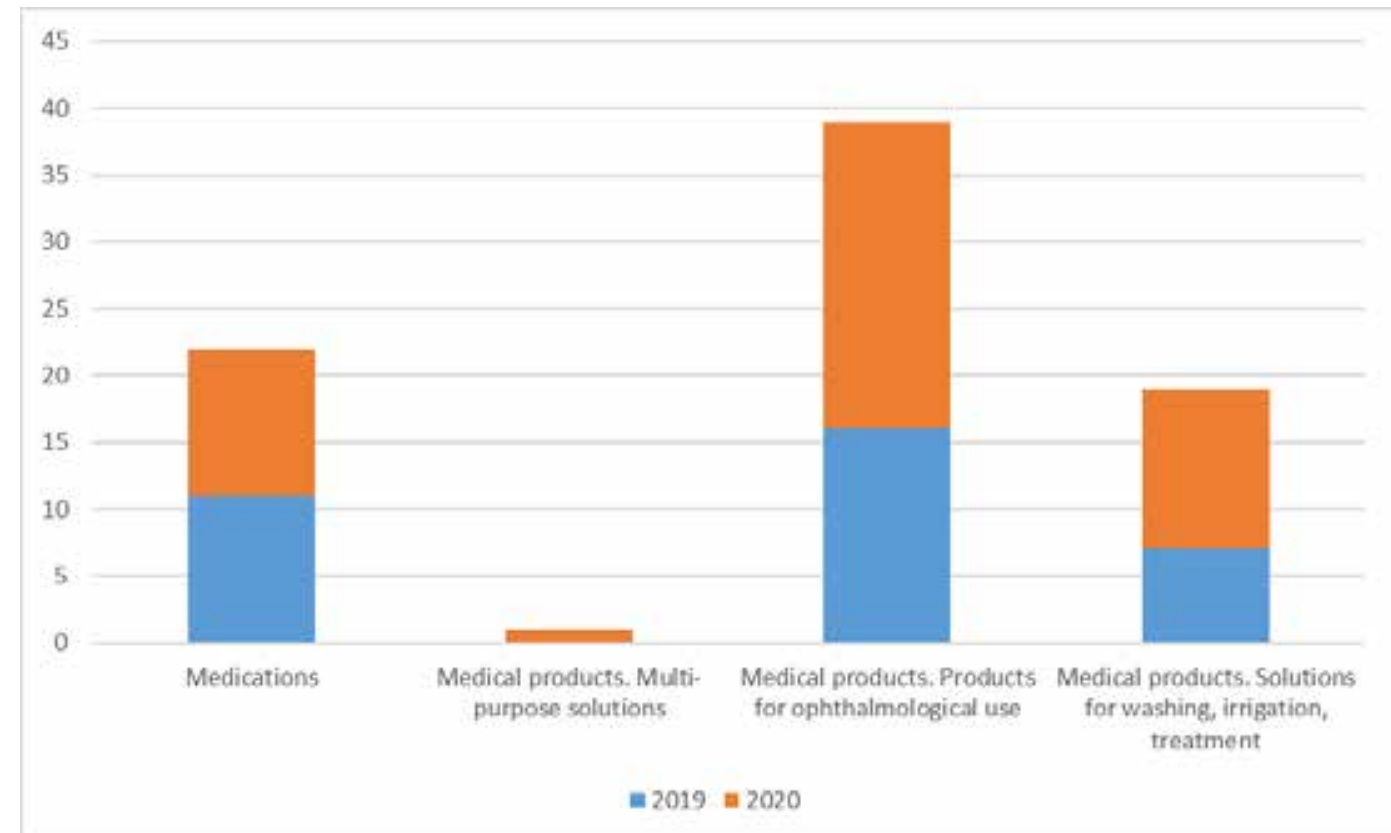

Fig. 1. Quantitative Indicators of the Pharmaceutical Market of DES STMs in Ukraine 


\section{Ways of ensuring sterility of substitution treatment medications}

The most widespread way of ensuring the sterility after the opening of original packaging of DES STMs is adding preservatives to their composition. Among the additive agents of this group, which have been detected in the course of the analysis of the composition of DES STMs that are present on the pharmaceutical market of Ukraine, there are both organic and inorganic ones, which by the class of chemical compounds belong to the Quaternary ammonium compounds or oxidants (Fig. 2).

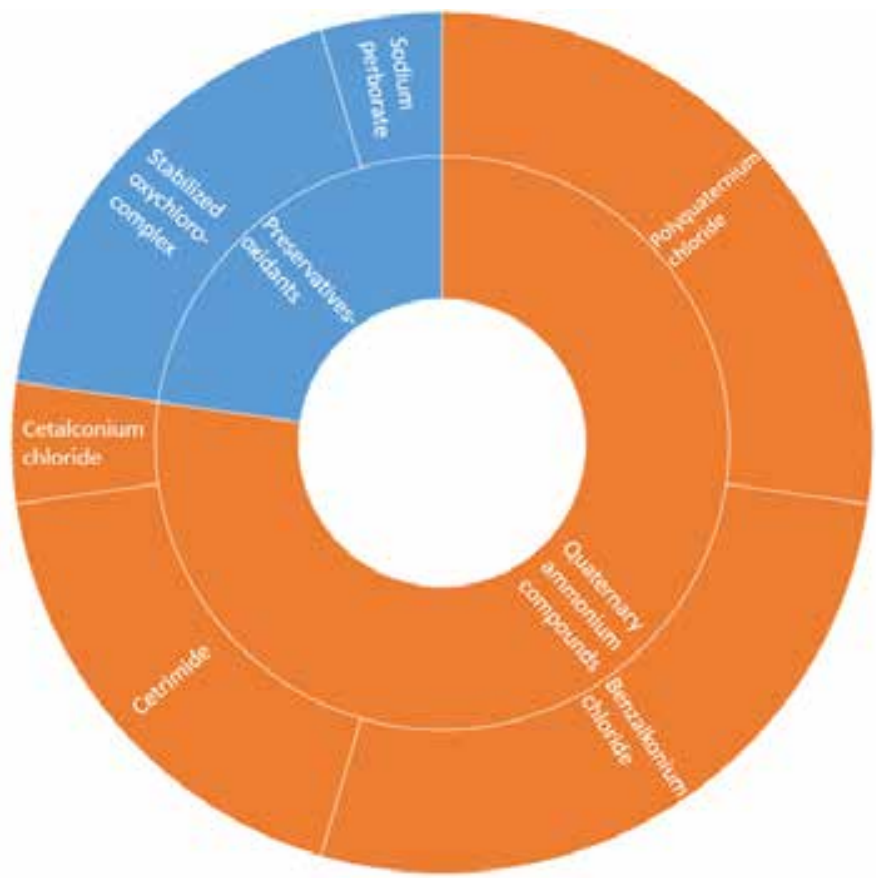

Fig. 2. The structure of oxidants and quaternary ammonium compounds used as preservatives of DES STMs

The inorganic antimicrobial preservatives are mainly presented by boric acid.

The representatives of preservatives-oxidants are sodium perborate (SUPEROPTIK AKVA eye drops $5 \mathrm{ml}$ vial, No.1, 2) and stabilized oxychlorocomplex (OPTIVE® eye drops $3 \mathrm{ml}, 10 \mathrm{ml}, 15 \mathrm{ml}$ in dropper vials No1, LUXIAL PLUS eye drops $10 \mathrm{ml}$, No.1, FLORA VISION dry eyes eye drops $15 \mathrm{ml}$, No.1, VIAL'® SLIOZA drops $10 \mathrm{ml}$ polyethylene vial, No.1).

However, Quaternary ammonium compounds are most frequently used as a preservative in STMs. Namely, these are benzalkonium chloride (VISILOTON OPHTHALMOLOGICAL MEDICATION 10 ml, No.1, HYPROMELOSA-P, eye drops 0.5\% container-dropper, $10 \mathrm{ml}$, No.1, OFTAGEL ${ }^{\circledR}$ eye gel, $2.5 \mathrm{mg} / \mathrm{g}, 10 \mathrm{~g}$ vial, 1 vial in a cardboard box, OFTOLIK eye drops of $5 \mathrm{ml}$ or $10 \mathrm{ml}$ in a plastic dropper vial, 1 dropper vial in a cardboard pack, OMK1 eye drops vial $10 \mathrm{ml}$, No.1, OMK2 eye drops vial $10 \mathrm{ml}$ sterile, No.1), cetalconium chloride (KATIONORM KRAPLI OCHNI $10 \mathrm{ml}$ emulsion, No.1), cetrimide (ARTELAK® eye drops, solution, $3.2 \mathrm{mg} / \mathrm{ml} 10 \mathrm{ml}$ in a dropper vial; 1 dropper vial in a box, VIDISIK eye gel $0.2 \% 10 \mathrm{~g}$ in a tube; 1 tube in a cardboard box, SIKAPOS eye gel, $2 \mathrm{mg} / \mathrm{g} 10 \mathrm{~g}$ in a tube, 1 or 3 tubes in a box, KERATOSTYL eye drops $10 \mathrm{ml}$ in a vial), polyquaternium 
chloride (TYRS natural II med. 15 ml, SYSTEIN BALANS ZASIB DLIA ZVOLOZHENNIA OCHEY $10 \mathrm{ml}$, No.1, SYSTEIN ULTRA ZASIB DLIA ZVOLOZHENNIA OCHEY $10 \mathrm{ml}$ vial. No.1, ZASIB D/ZVOLOZHEN. OCHEY SYSTEIN $10 \mathrm{ml}$ vial, No.1, EYE MOISTURIZER SYSTEIN® gel solution $10 \mathrm{ml}$ No.1, ARTIFICIAL TEARS eye drops $5 \mathrm{ml}$ or $10 \mathrm{ml}$, or $15 \mathrm{ml}$ in a "Drop-Tainer ${ }^{\circledR}$ " dropper vial; 1 dropper vial in a cardboard box).

However, it has been determined that some STMs, which according to their package inserts (instruction for medical application of a medication, instruction on the use of the medication and instruction on the use) do not contain preservatives, contain agents that have the ability to increase the microbiological stability of a solution under certain conditions. Such agents in the STM composition are boric acid, polyhexanide, citric acid, N-hydroxymethylglycinate, edetate sodium, trilon B, enoxolone glucuronide.

DES STMs that do not contain preservatives in their composition ad are packaged in vial for multiple use have specific corking tools to ensure the sterility and preservation of the properties of the eye drops after the opening of the original packaging. The AVAK filtrating membrane in the form of a multi-dose patented vial is used for packaging the TEALOZ® DUO ROZCHYN OFTALMOLOHICHNYI $10 \mathrm{ml}$ vial, sterile, No.1. In addition, the ophthalmic squeeze dispensers (OSD) are widely used (UNITIRS eye drops $10 \mathrm{ml}$ vial, No.1, GILAYS, sterile moisturizing ophthalmic solution with sodium hyaluronate $0.4 \%$, ophthalmic solution sterile $0.4 \%$ vial $10 \mathrm{ml}$, No. 1, OFTALGERD eye drops $10 \mathrm{ml}$, No.1, OFTASSIALE eye drops $10 \mathrm{ml}$, No.1, SAFLOGIAL eye drops $10 \mathrm{ml}$, No.1, UMASTAR eye drops $10 \mathrm{ml}$, No.1), airtight pumps (ARTELAK® SPLESK POZCHYN ZVOLOZHUYUCHYI DLIA OCHEY I KONTAKTNYKH LINZ $0.24 \%$ solution, $10 \mathrm{ml}$ vial, No.1, KHILOß-KEA eye drops $10 \mathrm{ml}$ multi-dose container with a pipe and a cap, No., VET-KOMOD eye drops, $20 \mathrm{mg} / \mathrm{ml} 10 \mathrm{ml}$ in a multi-dose plastic container, equipped with an air-tight pipe; 1 container in a card box, KHILO-KOMOD eye drops $1 \mathrm{mg} / \mathrm{ml}, 10 \mathrm{ml}$ in a multi-dose container, equipped with an air-tight pipe and closed with a cap, 1 container in a card box, KHILO-KOMOD FORTE eye drops, $2 \mathrm{mg} / \mathrm{ml}, 10 \mathrm{ml}$ in a multi-dose container, equipped with an air-tight pipe and closed with a cap, 1 container in a card box) and others.

Thus, the detected ways of ensuring the STM sterility after the opening of the original packaging include:

- adding preservatives;

- packaging in single-dose containers;

- using special corking tools.

National producers use all of the above mentioned ways of ensuring the sterility of DES STMs after the opening of the original packaging. However, the most often way is adding preservatives (3 medications), whereas the use of special corking tools and single-dose packaging is used for only 2 STMs.

The STMs that are produced abroad also use all of the ways of ensuring the sterility after opening the original packaging that are outlined in the State Pharmacopoeia of Ukraine; single-dose packaging - 1 medication, use of special corking tools -14 medications, adding preservatives -18 medications.

\section{Conclusions}

Provision of clear information in the labeling and the insert of the medication regarding the presence, name and quantity of a preservative (with the use of the term "preservative") is a necessary and often one of the determining factors in treatment selection for patients with DES. This is determined by the fact that certain agents (or their combination) may perform different 
functions in a medical form acting, depending on the, for instance, concentration, as preservatives, components of buffer solutions, antioxidants or isotonic substances.

The results of the study show that as of December, 2020 only a few of STMs presented on the pharmaceutical market of Ukraine contain such information.

\section{References}

Bron, A. J., dePaiva, C. S., Chauhan, S. K. et al. (2017). TFOS DEWS II pathophysiology report. The Ocular Surface, vol. 15, no. 3, pp. 438-510.

Craig, J. P., Nichols, K. K., Akpek, E. K. et al. (2017). TFOS DEWS II definition and classification report. The Ocular Surface, vol. 15, no. 3, pp. 276-283.

Derzhavna farmakopeia Ukrainy 2-e vyd. [State Pharmacopoeia of Ukraine 2-nd ed.] (2015). Kharkiv: Derzhavne pidpryiemstvo "Ukrainskyi naukovyi farmakopeinyi tsentr yakosti LZ". [in Ukrainian]

Derzhavnyj reyestr likars 'kykh zasobiv Ukrayiny [State Register of Medicines of Ukraine] (2019). Retrieved from: http://www.drlz.com.ua/ibp/ddsite.nsf/all/shlist?opendocument. [in Ukrainian] Derzhavnyj reyestr medychnoyi tekhniky ta vyrobiv medychnoho pryznachennya [State Register of Medical Equipment and Medical Devices] (2019). Retrieved from: http://dls.gov.ua/wp-content/uploads/2018/07/\%D0\%A0\%D0\%B5\%D0\%B5\%D0\%B5\%D1\%81\%D1\%82\%D1\%80. pdf. [in Ukrainian]

Dovidnyk likars'kykh zasobiv Kompendium [Medicines Reference Compendium]. (2019). Retrieved from: https://compendium.com.ua/uk. [in Ukrainian]

Elmer, Y. Tu. (2014). Balancing antimicrobial efficacy and toxicity of currently available topical ophthalmic preservatives. Saudi Journal of Ophthalmology, vol. 28, no. 3, pp. 182-187. Epstein, S. P. et al. (2009). Comparative toxicity of preservatives on immortalized corneal and conjunctival epithelial cells. Journal of Ocular Pharmacology and Therapeutics, vol. 25, no. 2, pp. 113-119.

Jones, L., Downie, L. E., Korb, D. et al. (2017). TFOS DEWS II management and therapy report. The Ocular Surface, vol. 15, no. 3, pp. 575-628.

Kryvoviaz, O. V., Tomashevska, Yu. O. (2019). Zasoby dlya zamisnoyi terapiyi syndromu sukhoho oka: analiz farmacevtychnoho rynku Ukrayiny [Remedies for substitution therapy of the dry eye syndrome: analysis of the pharmaceutical market of Ukraine]. Pharmaceutical Review, no. 4, pp. 37-44. [in Ukrainian]

Makarenko, O. V., Kryvoviaz, O. V., Tomashevska, Yu. O. (2015). Vplyv dopomizhnykh rechovyn u protyhlaukomnykh ochnykh krapliakh na pokaznyk yakosti zhyttia za kryteriiem chastoty pobichnykh efektiv [Influence of excipients in antiglaucoma eye drops on the quality of life by the criterion of frequency of side effects]. Farmatsevtychnyi Zhurnal, no. 3, pp. 39-44. [in Ukrainian] Marx, D., Birkhoff, M. (2010). New devices for dispensing ophthalmic treatments may be the key to managing the life cycles of established products. Drug Development \& Delivery, vol. 10, no. 9, pp. 16-21.

Marx, D., Birkhoff, M. (2015). Original packaging - Ophthalmic Squeeze Dispenser (OSD): Does One Size Fit All? Drug Development \& Delivery, vol. 15, no. 8, pp. 41-49.

McMonnies, $C$. W. (2021). Why the symptoms and objective signs of dry eye disease may not correlate. Journal Of Optometry, vol. 14, no. 1, pp. 3-10.

Syndrom sukhoho oka. Klinichna nastanova, zasnovana na dokazakh [Dry eye syndrome. Evidence-based clinical guidance]. (2019). Retrieved from: http://mtd.dec.gov.ua/index.php/uk/ haluzevi-standarty-ta-klinichni-nastanovy/item/421-syndrom-sukhoho-oka. [in Ukrainian] 